\title{
Perspectiva de alunos de ensino superior acerca de células troncos embrionárias
}

\section{Perspective of higher education students about embryonic stem cells}

\author{
${ }^{1}$ Lundoi Tobias Lee lundoilee@id.uff.br \\ ${ }^{2}$ Luciana Cristina do Carmo Silva Carvalho \\ ${ }^{3}$ Sabrinna Aires Garcia
}

\section{RESUMO}

O século XXI é marcado pelo avanço tecnológico, evolução na medicina, renovação na pesquisa científica e difusão do conhecimento, além do cenário da informação e comunicação da sociedade ter sido modificado com a era da internet, essas novas tecnologias têm transformado a realidade humana diretamente. Influenciando nas questões sociais, políticas, culturais e econômicas. Um dos temas revolucionários dessa nova fase são as células-tronco, que são células com capacidade de autorrenovação e de diferenciação, têm capacidade de se dividir e se transformar em outros tipos de células. Os principais tipos de células-tronco são as embrionárias e as adultas, o estudo e a aplicação da terapia com células-tronco desencadeia a dualidade de convicções, por um lado: a esperança e a perspectiva da melhora na saúde humana. Por outro lado: a insegurança na real eficácia e ferir os princípios morais na utilização de embriões humanos. O objetivo desse estudo foi investigar o conhecimento de estudantes de ensino superior no Brasil, acerca do tema sobre células-tronco, e a utilização de células-tronco embrionárias para fins terapêuticos, onde foi realizado um questionário de múltipla escolha por meio digital, apresentando respostas de caráter fechado. Esse estudo demonstrou que muitos acadêmicos são favoráveis a utilização de células-tronco embrionárias como alternativa terapêutica, mesmo não demonstrando conhecimento concreto e conciso a respeito do conceito científico de células-tronco embrionárias.

Palavras-chaves: Conhecimento científico. Bioética. Educação. Biotecnologia.

\section{ABSTRACT}

The 21st century is marked by technological breakthroughs, improvement in medicine, renewal in scientific research and knowledge sharing, in addition to the scenario of information and communication in society having been modified within the internet era, these new technologies have changed human reality directly. Influencing on social, political, cultural and economic matters. One of the revolutionary subjects of this new stage is stem cells which are cells, which are cells capable of self-renew and differentiation, have the ability to fractionate and change into other cells. The main types of stem cells are embryonic and adult, the study and application of stem cell therapy triggers the duality of convictions, on one hand: hope and the prospect of the improvement in human health. On the other hand: insecurity with its effectiveness and defile moral principles with the use of human embryos. This study goal was to investigate the comprehension of university students in Brazil, in the topic of stem cells, and the use of embryonic stem cells for therapeutic purposes, where a multiple-choice quiz was managed digitally, presenting answers closed character. This study demonstrated that many scholars are in favor of using embryonic stem cells as a therapeutic alternative, even though they do not demonstrate concrete and concise knowledge about the scientific concept of embryonic stem cells.

Keywords: Scientific knowledge. Bioethics. Education. Biotechnology.

\footnotetext{
1 Doutora em Microbiologia Agrícola pela Universidade Federal de Lavras. Universidade Federal de Lavras.

2 Mestre em Tecnologia Ambiental pela Universidade Federal Fluminense. Universidade Federal Fluminense.

3 Graduanda em Engenharia de Agronegócio pela Universidade Federal Fluminense. Universidade Federal Fluminense.
} 


\section{INTRODUÇÃO}

Partindo do princípio da beneficência, ou seja, maximizar o benefício e minimizar o prejuízo, um dos objetivos da medicina é melhorar o bem-estar. Do mesmo modo que cientistas afirmam que o objetivo da pesquisa com células-tronco embrionárias humanas é encontrar tratamento para doenças. $\mathrm{O}$ uso de embriões humanos para fins de pesquisa levanta questões éticas, nesse âmbito, os líderes religiosos desempenham papel de termômetro moral envolvendo a comunidade científica e a sociedade (SIVARAMAN, 2019). Nos últimos anos, assuntos científicos passaram a ser veiculados nos meios de comunicação de massa, popularizando temas biológicos como clonagem, transgênicos, células-tronco, entre outros, informações que anteriormente eram apenas acessíveis as comunidades científicas passou a fazer parte do cotidiano do público geral, assim desencadeando controvérsias políticas e morais. E a internet proporcionou acesso amplo e fácil a informações e em alguns casos essas inverídicas.

As células que formam o corpo humano são divididas basicamente em três classes: células germinativas, células somáticas e células-tronco. As células somáticas são uma massa celular que formam os órgãos, tecidos e o corpo humano adulto, cada uma dessas células em seu estado diferenciado tem sua própria cópia, ou cópias, do genoma; a única exceção ocorre com os glóbulos vermelhos que são células anucleadas. As células que dão origem aos gametas (óvulos e espermatozoides) são chamadas de germinativas. Células-tronco são definidas como células que apresentam capacidade de se dividir indefinidamente em cultura e com o potencial de dar origem a células especializadas adultas (ALISON et al., 2002; BONGSO e RICHARDS, 2004).

As células-tronco são variadas, as células oriundas das duas primeiras divisões do zigoto são chamadas totipotentes, capazes de formar o embrião e trofoblasto da placenta. Essas células totipotentes após o período de quatro dias começam a se especializar, formando o blastocisto e um aglomerado de células chamado massa interna celular. Essas células da massa interna celular são consideradas pluripotentes, capazes de se diferenciar em quase todas as células que dão origem as três camadas germinativas (ectoderma, mesoderma e endoderma), mas não ao embrião em si devido a incapacidade de originarem a placentas e tecidos de suporte. A maior parte dos tecidos apresentam células multipotentes, responsáveis pela manutenção dos mesmos e capazes de produzirem linhagens celulares limitadas e diferenciadas de acordo com o local de origem (ALISON et al., 2002; ARAGÃO e BEZERRA, 2012; SLACK, 2018).

A obtenção de células-tronco embrionárias é possível a partir da idade de três semanas, quando ocorre a fase de gastrulação. Entretanto, obter embriões com essa idade é extremamente difícil, com a interrupção de gravidez os embriões não permanecerão intactos. Uma alternativa seria realizar a fertilização in vitro e permitir que os embriões se desenvolvam até o estágio de três semanas, porém essa prática não é permitida, pois fere o consenso ético e as leis de muitos países, embriões humanos não podem ser cultivados in vitro além de 14 dias (POURQUIÉ, 2018). A polêmica da utilização de células-tronco embrionárias está relacionada com o questionamento de quando se inicia a vida, e se o embrião é de fato uma pessoa humana.

No Brasil existe a lei da Biossegurança, Lei nº 11.105, de 24 de março de 2005, referente à pesquisa com células-tronco embrionárias, onde é permitida, para fins de pesquisa e terapia, a utilização de células-tronco embrionárias obtidas de embriões humanos produzidos por fertilização in vitro e não utilizados no respectivo procedimento, atendidas as seguintes condições: sejam embriões inviáveis; ou; sejam embriões congelados há 3 (três) anos ou mais; em qualquer caso, é necessário o consentimento dos genitores. Instituições de pesquisa e serviços de saúde que realizem pesquisa ou terapia com células-tronco embrionárias humanas deverão submeter seus projetos à apreciação e aprovação dos respectivos comitês de ética em pesquisa; é vedada a comercialização do material biológico a que se refere este artigo e sua prática implica o crime tipificado. Sendo proibido: desenvolver projetos sem avaliação de comitês de ética, engenharia genética e clonagem humana.

Ao longo da trajetória educacional alunos do nível superior, tiveram ou deveriam ter tido acesso a aulas que abordaram o assunto células-tronco, a relevância do conhecimento no assunto está relacionada ao fato que o indivíduo como cidadão, munido de conhecimento base e informações possa tomar decisões conscientes e escla- 
recidas, participar de modo crítico e democrático em debates sobre esses assuntos. Diante do exposto, o objetivo desse estudo foi avaliar o conhecimento de alunos do ensino superior nas instituições brasileiras a respeito do conhecimento acerca de células-tronco embrionárias, devido ao fato de ser um tema que acarreta em discussões, bem como por ser uma alternativa terapêutica para tratar inúmeras patologias.

\section{METODOLOGIA}

O estudo se desenvolveu através de aplicação de questionário por meio digital, com auxílio de redes sociais para divulgação. Dentro dos critérios do questionário foi obtido o rendimento de 410 participantes, entre eles nos níveis educacionais de graduação, mestrado e doutorado, divididos nas grandes áreas de ensino Ciências Humanas, Biológicas e Exatas, os questionários que apresentaram respostas para a questão do nível educacional abaixo do nível de graduação foram descartados.

O questionário continha questões a respeito do perfil dos participantes como grau de instrução, idade e questões relacionadas a células-tronco como o que são e os tipos, se o participante tinha conhecimento sobre o tema e se era a favor ou contra a utilização de células-tronco para fins terapêuticos.

\section{RESULTADOS E DISCUSSÃO}

A faixa etária que apresentou maior número de participantes estavam entre 25 a 29 anos com 184 pessoas, seguidos por 98 participantes na faixa etária de 30 a 34 anos, 87 participantes com idade entre 19 a 24 anos, 39 pessoas com idade superior a 35 anos e apenas dois participantes com idade inferior a 18 anos. Nesse cenário, o maior número de participantes (193) está no nível de mestrado, e na sua grande maioria são da área de Ciências Biológicas com 216 representantes, como demonstrado na Tabela 1.

Tabela 1. Perfil dos participantes

\begin{tabular}{lccccccc}
\hline & \multicolumn{3}{c}{ Ciências } & \multicolumn{3}{c}{ Nível } \\
\cline { 2 - 8 } Idade & Participantes & Humanas & Biológicas & Exatas & Graduação & Mestrado & Doutorado \\
\hline $\mathbf{1 0}$ & 2 & 0 & 2 & 0 & 2 & 0 & 0 \\
\hline $\mathbf{1 9 - 2 4}$ & 87 & 27 & 45 & 15 & 58 & 26 & 3 \\
\hline $\mathbf{2 5 - 2 9}$ & 184 & 46 & 83 & 55 & 45 & 110 & 29 \\
\hline $\mathbf{3 0 - 3 4}$ & 98 & 18 & 63 & 17 & 11 & 44 & 43 \\
\hline$>\mathbf{3 5}$ & 39 & 5 & 23 & 11 & 13 & 13 & 13 \\
\hline
\end{tabular}

Fonte: Elaborada pelos autores (2019).

Após as perguntas para identificar o perfil dos participantes, o questionário foi iniciado com a seguinte pergunta: "Você sabe o que são e quais os tipos de células-tronco?". E como alternativa de resposta havia a opção "Sim" caso a resposta fosse positiva e "Não" caso a resposta fosse negativa, e o resultado obtido para essa questão foi que 33\% dos participantes disseram não saber a resposta correta como mostra a Figura 1, onde os resultados foram subdivididos de acordo com o nível acadêmico. 
Figura 1. Participantes que afirmaram não saber o que são células-tronco.

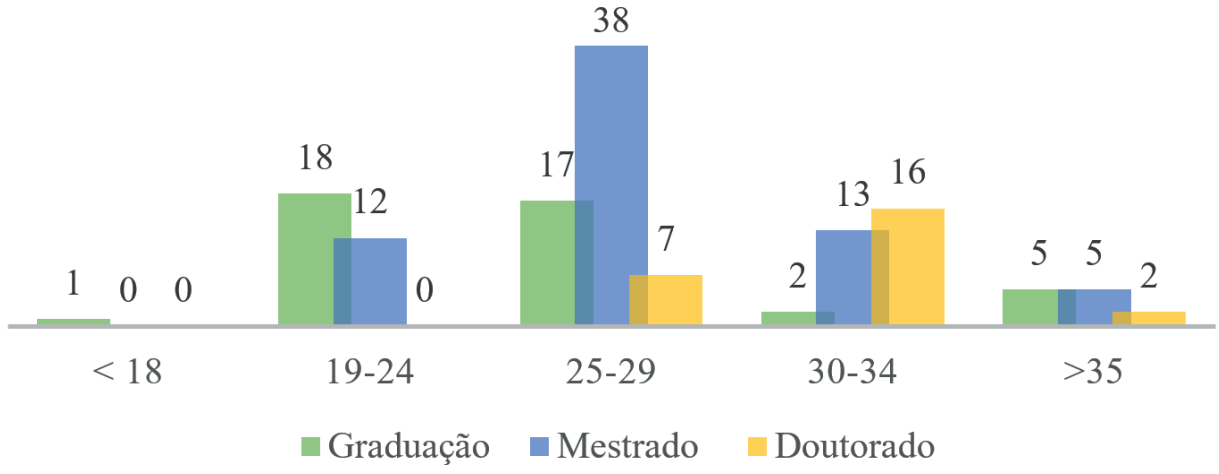

Fonte: Elaborada pelos autores (2019).

Em contrapartida, 67\% dos participantes disseram saber o que são células-tronco, de acordo com a Figura 2.

Figura 2. Participantes que afirmaram saber o que são células-tronco.

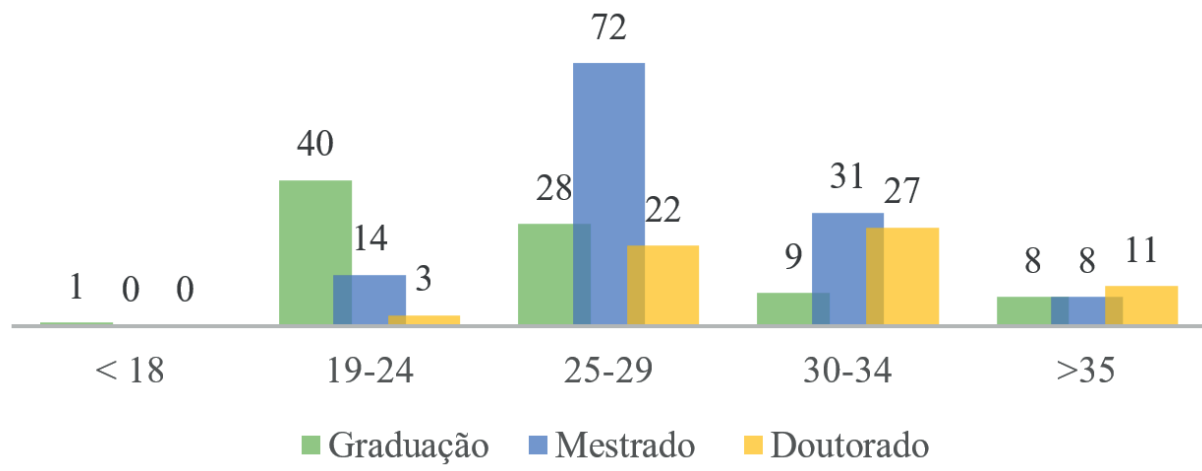

Fonte: Elaborada pelos autores (2019).

Subsequente foi realizado a pergunta: “O que são células-tronco?” que apresentava cinco alternativas para resposta. Considerou-se na alternativa (a) "São células especializadas da medula que são responsáveis pela manutenção dos órgãos", e foram obtidos os seguintes resultados, como representado na Figura 03, onde 28 participantes marcaram essa resposta como a correta, representando 6,83\%:

Figura 3. Participantes que optaram pela alternativa: a) "São células especializadas da medula que são responsáveis pela manutenção dos órgãos.”

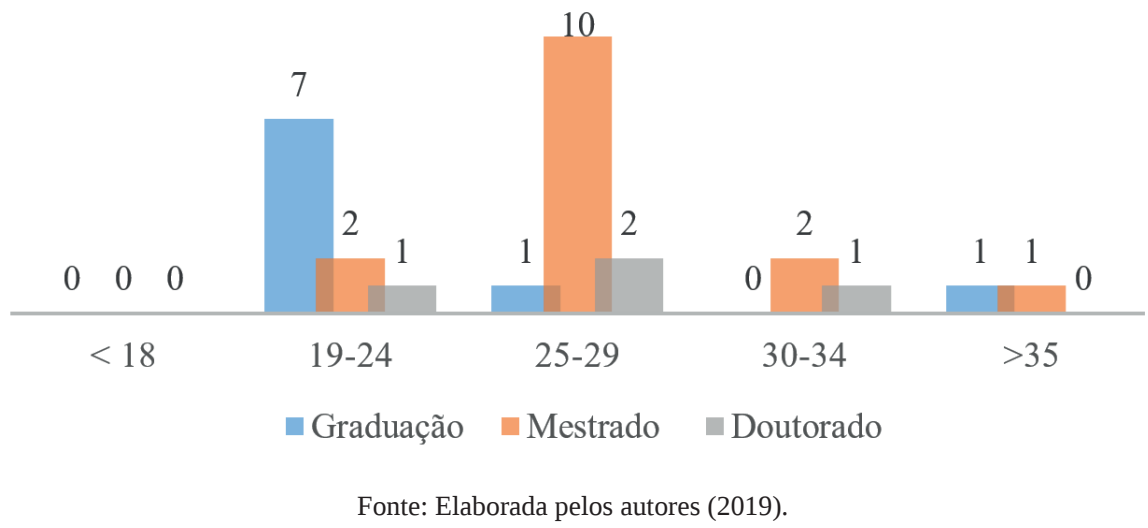


Como resposta da alternativa (b) "São células que constituem o sangue e ajudam no sistema imunológico”, três participaram marcaram essa alternativa como a resposta mais adequada para a questão, representando 0,73\% dos participantes, como apresentado na Figura 4:

Figura 4. Participantes que optaram pela alternativa: b) "São células que constitui o sangue e ajudam no sistema imunológico"

\begin{tabular}{|c|c|c|c|c|}
\hline $\begin{array}{lll}0 & 0 & 0\end{array}$ & $\begin{array}{lll}0 & 0 & 0\end{array}$ & $\begin{array}{lll}1 & 0 & 0\end{array}$ & $\begin{array}{ll}0 & 0\end{array}$ & $\begin{array}{lll}0 & 1 & 1\end{array}$ \\
\hline \multirow[t]{2}{*}{$<18$} & $19-24$ & $25-29$ & $30-34$ & $>35$ \\
\hline & - Graduação & Mestrado & ఐ Doutorado & \\
\hline
\end{tabular}

Fonte: Elaborada pelos autores (2019).

No caso da terceira alternativa (c) "São células que possuem potencial de auto-renovação e diferenciação.”, sendo a resposta mais adequada para a questão, 344 participantes marcaram essa alternativa, representando 83,90\% dos participantes, como demonstra a Figura 5:

Figura 5. Participantes que escolheram como alternativa correta: c) "São células que possui potencial de auto-renovação e diferenciação.”

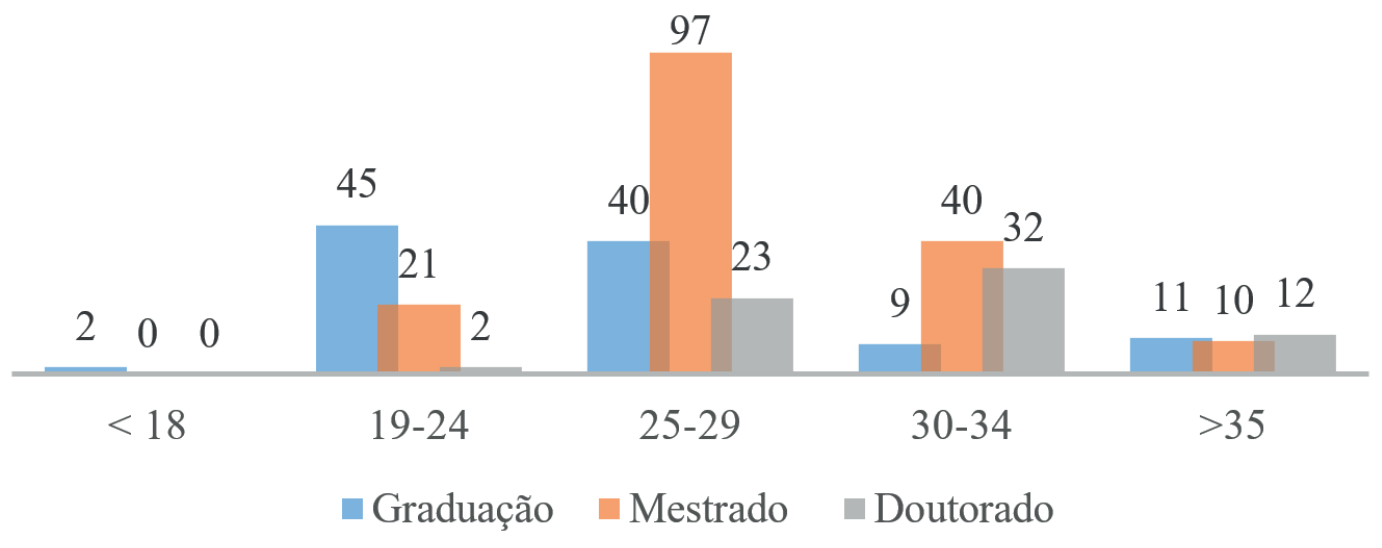

Fonte: Elaborada pelos autores (2019).

Para a quarta opção (d) "São as células neurais que podem reconstituir neurônios", foi escolhida por quatro participantes como a alternativa mais apropriada para responder a questão, representando $0,97 \%$ dos participantes, apresentados na Figura 6: 
Figura 6. Participantes que escolheram: d) "São as células neurais que podem reconstituir neurônios"

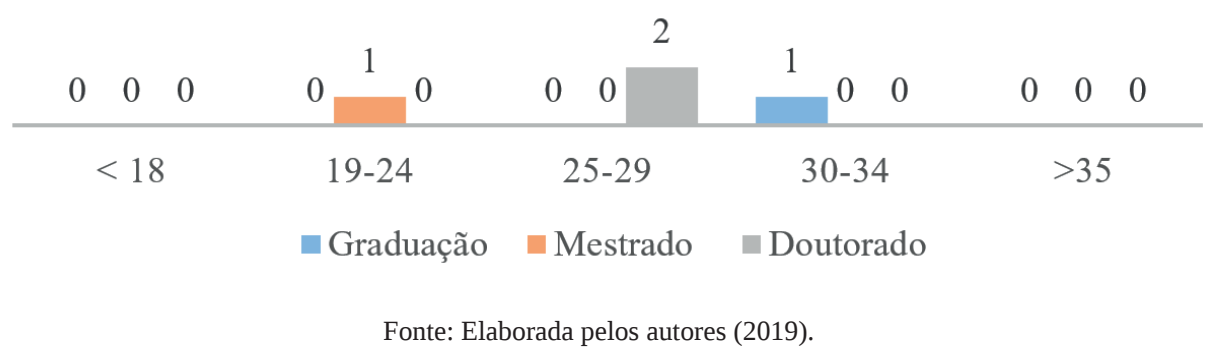

E como resposta da última alternativa, os participantes puderam optar por (e) "Não sei responder", 31 participantes optaram por essa alternativa, representando 7,56\%, apresentados na Figura 7:

Figura 7. Participantes que optaram pela alternativa: e) “Não sei responder”

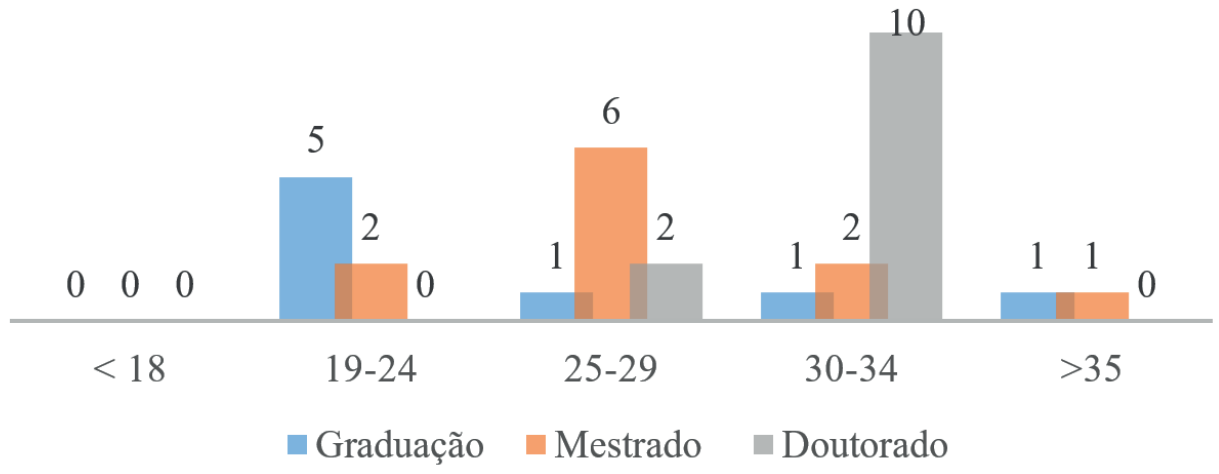

Fonte: Elaborada pelos autores (2019).

Prosseguindo com o questionário com o intuito de analisar o conhecimento dos participantes acerca do tema proposto, foi realizada a pergunta: "Sobre células-tronco embrionárias, de onde podem ser extraídas? (Existem três tipos de células-tronco que podem ser adultas, mesênquimais ou embrionárias.)". Como alternativas de resposta foram apresentadas quatro opções, a primeira opção apresentava a seguinte resposta: 1) "São provenientes do feto". Essa resposta foi escolhida por 58 participantes, representando 14,15\%, de acordo com a Figura 8:

Figura 8. Representatividade dos participantes que optaram pela alternativa: 1) "São provenientes do feto".

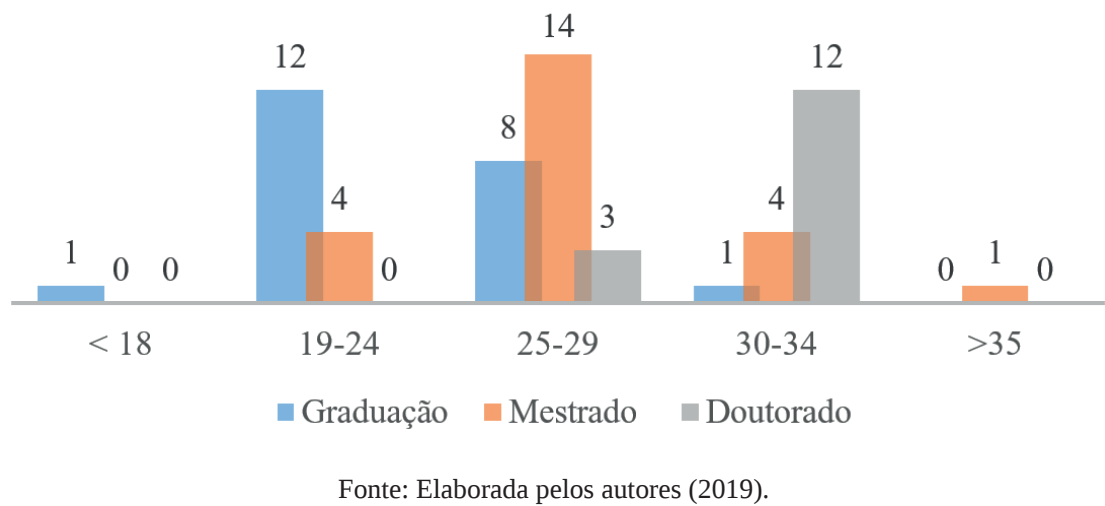


A segunda alternativa para a resposta para essa questão: 2) "São provenientes do óvulo fecundado e tecidos extraembrionários”, sendo a resposta mais adequada para responder à questão, 194 participaram escolheram essa opção como a mais correta, representando 47,32\%, como exibido na Figura 9:

Figura 9. Integrantes que optaram pela alternativa: 2) “São provenientes do óvulo fecundado e tecidos extraembrionários”

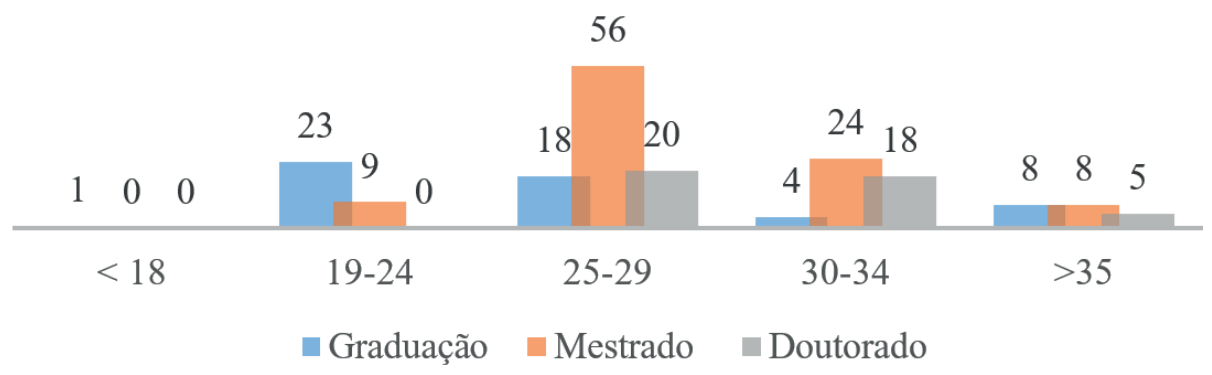

Fonte: Elaborada pelos autores (2019).

A resposta da terceira opção alegava que as células-tronco embrionárias: 3) "São provenientes do cordão umbilical somente”, para essa alternativa 147 participantes acreditavam ser a mais adequada para a questão, representando 35,85\% (Figura 10).

Figura 10. Participantes que escolheram: 3) "São provenientes do cordão umbilical somente”.

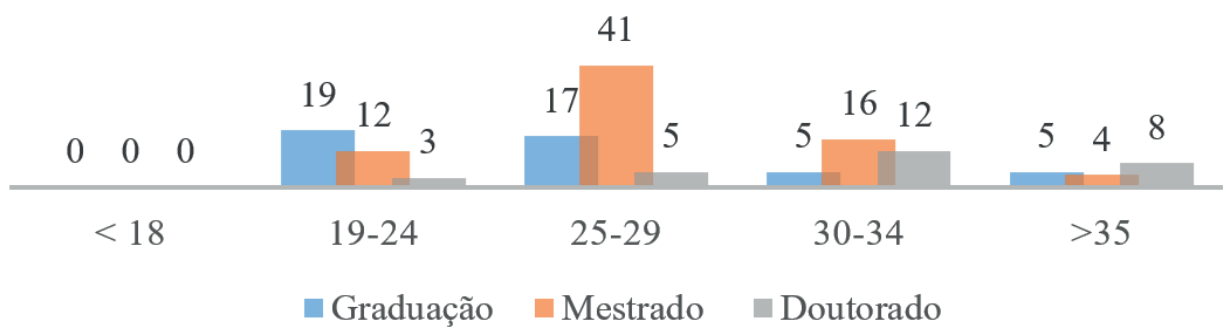

Fonte: Elaborada pelos autores (2019).

E a última alternativa proposta para essa questão afirma que a origem das células-tronco embrionárias: 4) "São provenientes da primeira coleta de sangue do bebê após o parto". Essa opção foi escolhida por 11 participantes, representando 2,68\%, mostrado na Figura 11. 
Figura 11. Relação dos participantes que optaram pela alternativa: 4) "São provenientes da primeira coleta de sangue do bebê após o parto”.

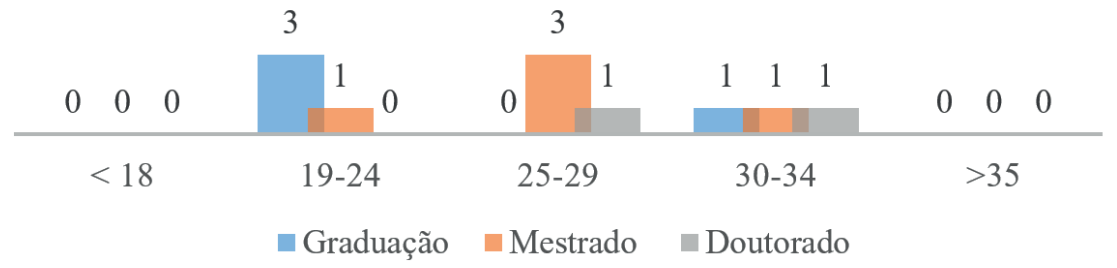

Fonte: Elaborada pelos autores (2019).

Finalizando o questionário foi realizada a seguinte pergunta: "De acordo com seus conhecimentos sobre o assunto, qual a sua opinião em relação ao uso de células-tronco embrionárias extraídas do embrião para fins terapêuticos?", para essa pergunta os participantes puderam optar por duas alternativas, sendo a primeira delas: 1) "Sou a FAVOR do uso de células-tronco embrionárias provindas do embrião para usos terapêuticos”, essa alternativa foi escolhida por 369 participantes, representando 90\%, apresentados na Figura 12.

Figura 12. Participantes que alegam ser a FAVOR do uso de células-troncos provindas de embriões para fins terapêuticos.

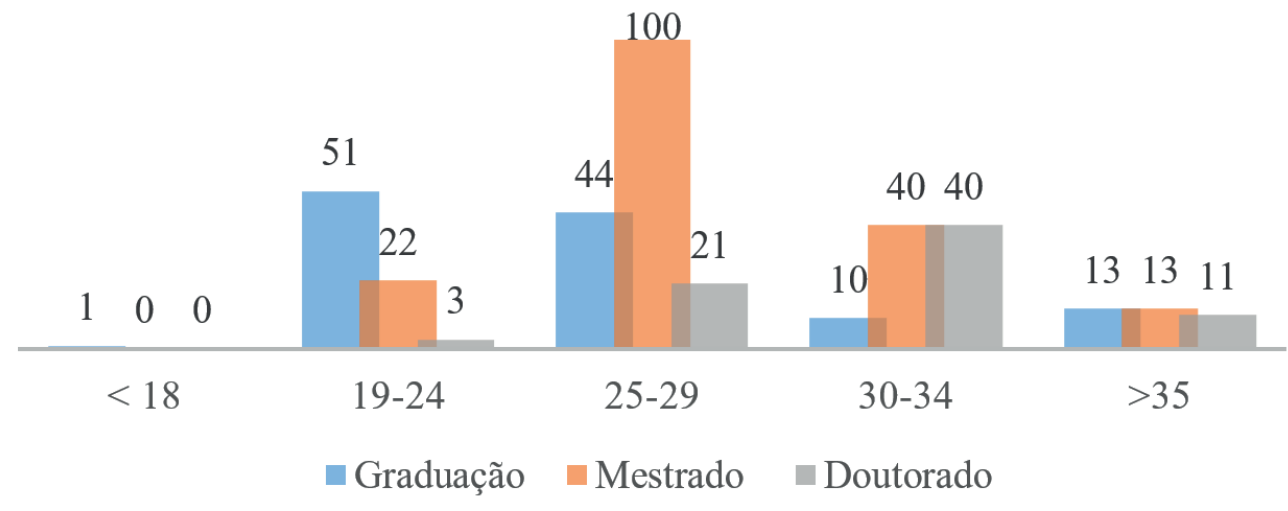

Fonte: Elaborada pelos autores (2019).

A segunda alternativa: 2) "Sou CONTRA o uso de células-tronco embrionárias provindas do embrião para uso terapêuticos”, 41 participantes escolheram essa opção, representando 10\%, de acordo com a Figura 13. 
Figura 13. Representantes que alegam ser CONTRA o uso de células-tronco provindas de embriões para uso terapêuticos.

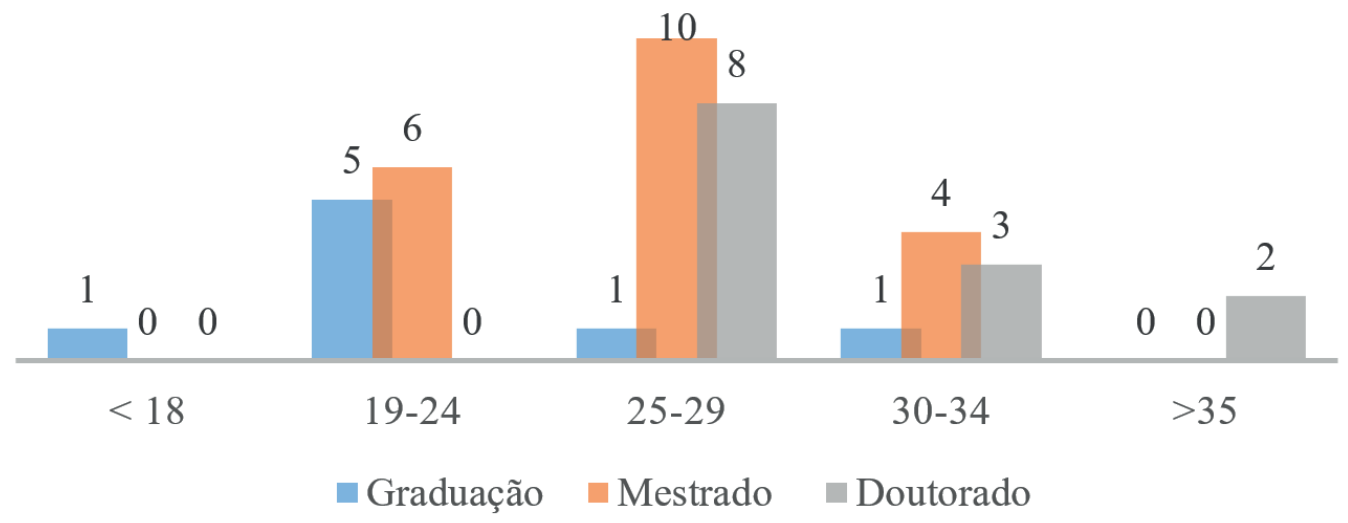

Fonte: Elaborada pelos autores (2019).

Dentro desse contexto dos 369 participantes que alegam ser a FAVOR do uso de células-tronco embrionárias, entre eles 170 participantes escolheram a alternativa que alega que células-tronco embrionárias são provindas de óvulos fecundados e tecidos extraembrionários, 128 também afirmaram NÃO saberem o que são e quais os tipos de células-tronco, e entre esses 128 participantes, 47 deles escolheram a alternativa mais adequada para definir o que são células-tronco. No caso dos participantes que são CONTRA o uso de células-tronco embrionárias para fins terapêuticos, entre os 41 que optaram por essa alternativa, 22 deles optaram pela opção mais adequada dentre as apresentadas para definir células-tronco embrionárias, três participantes alegaram não saber a definição correta e ainda assim escolheram a alternativa mais adequada, como demonstrada na Tabela 2.

Tabela 2. Opinião dos participantes sobre utilizar células tronco embrionárias.

\begin{tabular}{lcc}
\hline \multirow{2}{*}{ Participantes } & A FAVOR & CONTRA \\
\cline { 2 - 3 } & 369 & 41 \\
\hline $\begin{array}{l}\text { Demonstraram conhecimento a } \\
\text { respeito do que são células-tronco }\end{array}$ & 170 & 22 \\
\hline $\begin{array}{l}\text { Responderam não saber o que são } \\
\text { células troncos e seus tipos }\end{array}$ & 128 & 3 \\
\hline $\begin{array}{l}\text { Responderam não saber o que são, } \\
\text { porém optaram pela resposta mais } \\
\text { adequada }\end{array}$ & 47 & 3 \\
\hline $\begin{array}{l}\text { Optaram pela alternativa incorreta } \\
\text { da definição de células-tronco } \\
\text { embrionárias }\end{array}$ & 152 & 19 \\
\hline
\end{tabular}

Fonte: Elaborada pelos autores (2019).

Os resultados obtidos nesse questionário demonstraram que independente de saberem o conceito correto a respeito de células-tronco embrionárias, a grande maioria dos participantes é a favor dessa prática como fins terapêuticos, entrando em concordância com os resultados obtidos no estudo desenvolvido por Aragão e Bezerra, (2012), que realizaram uma visão geral das pesquisas com células-tronco no Brasil, concluíram que o Brasil apresentou grandes progressos com pesquisas nessa área e apresenta grande potencial, resultando em pesquisadores entusiasmados, e população geral esperançosa, mesmo que as pesquisas desenvolvidas sejam em pequena escala. 
No estudo desenvolvido por Oliveira et al., (2008), que tinha como objetivo avaliar o conhecimento sobre células-tronco dos alunos de cursos de graduação da área da saúde da Universidade Estadual de Londrina, onde buscaram saber o conhecimento dos alunos e o posicionamento do tema, abordaram questões éticas, religiosas, e questões como quando se inicia a vida. Observaram que os alunos tinham mais dificuldades quando questionados sobre células-tronco adultas do que quando questionados sobre células-tronco embrionárias, correlacionaram esse fato com a ocorrência desse tema ser abordado com mais intensidade pela mídia em geral. E concluíram que o tema ainda não faz parte do cotidiano dos alunos no que se refere à informação e conhecimento.

As respostas obtidas por Fujii et al., (2009), que investigaram o conhecimento de acadêmicos, do primeiro e último ano dos cursos de Direito, Medicina e Ciências Biológicas sobre células-tronco e suas opiniões a respeito de sua aplicabilidade, de uma universidade pública da região noroeste do estado do Paraná, no Brasil. Aplicaram questionário dissertativo e concluíram que a maior parte dos entrevistados tem um conhecimento genérico e superficial acerca do tema, demonstrando confusão e irregularidade em relação ao conceito científico.

Ao serem questionados sobre seu posicionamento em relação às pesquisas com células-tronco, a grande parte dos entrevistados por Fujii et al., (2009), apesar de muitos terem revelado uma ideia concepcionista sobre o início da vida, disseram ser a favor da utilização de células-tronco para fins terapêuticos, por representar uma esperança de cura para determinadas doenças, tidas atualmente como incuráveis, bem como aumento da longevidade humana. Alguns alunos defenderam seu posicionamento argumentando que este tipo de pesquisa representa inovação e desenvolvimento tecnológico, bem como esperança em terapias que possibilitem a substituição de células danificadas e doentes, por células sadias, em vez dos atuais transplantes.

Os resultados encontrados por Oliveira et al., (2008) e Fujii et al., (2009), são semelhantes aos obtidos nesse estudo, devido ao fato de que embora muitos dos alunos não tenham conhecimento concreto e científico sobre células-tronco, ainda assim entendem e acreditam ser uma alternativa terapêutica e um progresso no ramo científico, que objetiva a melhoria da vida humana.

O conhecimento e a atitude dos membros da equipe de profissionais de saúde e estudantes da Universidade King Abdulaziz foi avaliado por Alzahrani, (2019)health professionals, and students in King Abdulaziz university (KAU, sobre células-tronco e suas aplicações, foi observado que quanto maior o grau de instrução, maior era o conhecimento sobre o assunto e mais favorável a utilização de terapias com células-tronco. A maioria dos participantes tinha conhecimento adequado sobre células-tronco, atitudes positivas em relação a pesquisas com células-tronco e importância da ética nas pesquisas científicas. As crenças religiosas e a idade não afetaram o conhecimento dos entrevistados sobre células-tronco, nem sobre seus pontos de vista em relação à ética em pesquisa.

Buscando avaliar a percepção de alunos do ensino fundamental, Lemes et al., (2017), realizou aplicação de questionário abordando questões envolvendo a utilização de células-tronco embrionárias, os resultados mostraram opiniões divididas dos estudantes, apresentando respostas positivas ao se indagar se a destruição do blastocisto era o aniquilamento de uma vida (62\%) e quanto à autorização para utilizar embriões congelados e não utilizados para pesquisa científica (50\%). Destes, 19,1\% mudariam suas opiniões se o caso envolvesse salvar a vida de um descendente. Em embriões congelados para fertilização que não tiveram uso, 78\% foram a favor da doação para casais inférteis e 19,2\% a favor de pesquisa com fins terapêuticos. Os autores relataram que ocorreu uma grande inversão de opiniões quando a questão passava para nível pessoal, podendo atingir um ente próximo. As respostas se tornaram divididas e por vezes até contraditórias.

Esse comportamento divergente pode ter ocorrido devido ao fato de não haver conhecimento conciso sobre o assunto da parte do participante, como também o apelo afetivo, onde a escolha da resposta pode ter sido baseada apenas no sentimento pelo ente querido em questão, ignorando todo o contexto abordado.

O estudo com células-tronco tem crescido muito nos últimos anos, e o Brasil também tem desenvolvido pesquisas sobre o tema, e a produção científica nacional sobre células-tronco publicadas entre os períodos de 
2013 a 2017 sofreu grande progresso, totalizando a produção de 10.569 documentos. Desses documentos, 72,2\% são artigos, $18 \%$ artigos de revisão, 4,8\% são capítulos de livros, 1,2\% são livros, 1,0\% são trabalhos em eventos e 2,8\% são os demais tipos de documentos. Quanto a produção tecnológica, observou-se que o número de patentes em células-tronco totalizou em 1.375 documentos (BOCHI et al., 2018).

\section{CONCLUSÃO}

A temática células-tronco é bastante controversa, no Brasil e no mundo. Em relação a realidade do nosso país, independente de opiniões favoráveis ou contrárias, os resultados mostraram a necessidade de o tema ser discutido e da população em geral e principalmente a comunidade acadêmica inteirar-se sobre o assunto, conhecer todas as implicações relacionadas a essa questão.

A grande maioria dos alunos de ensino superior do Brasil que responderam o questionário, não tem conhecimento concreto e conciso a respeito do tema células-tronco, mas ainda assim são favoráveis a utilização de células-tronco e células-tronco embrionárias para fins terapêuticos. Mesmo apresentando conhecimento superficial e muitas vezes genérico sobre o assunto, entende em sua maioria que pode ser uma alternativa terapêutica de sucesso.

Esses resultados mostram que mesmo com acesso à informação e métodos facilitados de se adquirir conhecimento, há falhas nesse processo, mesmo assuntos que são frequente e constantemente abordados na mídia, existe um déficit acerca de conhecimentos concretos, onde muitas vezes só se tem conhecimento de forma vaga e imprecisa do tema, desse modo as instituições de ensino desempenham papel fundamental em proporcionar formação de qualidade, sendo necessária a reestruturação da grade curricular, tornando-a mais adequada e atualizada as atuais necessidades científicas.

Para a construção de conhecimento em sala de aula se faz necessário uma dinâmica diante das inovações tecnológicas e científicas, agregar novas e atualizadas informações ao material didático, urgência dos educadores se manterem atualizados em variadas áreas. Esse estudo colaborou de forma modesta para avaliação da qualidade da educação, outros estudos são necessários para contribuir de forma efetiva na melhoria do ensino.

\section{REFERÊNCIAS}

ARAGÃO, M.A.C.; BEZERRA, F.T.G. Brasil e as pesquisas com células-tronco: visão geral. Revista da Biologia, v. 9, n. 1, p. 12-15, 2012. Disponível em: <http://www.ib.usp.br/revista/node/132>.

ALISON, M.R.; POULSOM, R.; FORBES, S.; WRIGHT, N.A. An introduction to stem cells. The Journal of Pathology, v. 197, n. 4, p. 419-423, jul. 2002. Disponível em: <http://www.ncbi.nlm.nih.gov/pubmed/12115858>. Acesso em: 16 fev. 2019.

ALZAHRANI FAISAL A. Knowledge of and attitudes towards stem cells and their applications: A questionnairebased cross-sectional study from King Abdulaziz university A potential molecular mechanism and biochemical alterations associated with bromuconazole-induced testicular t. Arabian Journal of Medical Sciences, [s. 1.], p. 18-21, 2019. Disponível em: https://doi.org/10.5455/ajms.31. Acesso em: 24 out. 2020.

BOCHI, F.; JUNIOR, R.F.G.; ALVES, T.M.; MOURA, A.M.M. de. Produção científica brasileira e patentes depositadas no Brasil em células-tronco. P2P E INOVAÇÃO, v. 5, n. 1, p. 26-42, 7 set. 2018. Disponível em: $<$ http://revista.ibict.br/p2p/article/view/4373/3751>. Acesso em: 17 fev. 2019.

BONGSO, A.; RICHARDS, M. History and perspective of stem cell research. Best Practice and Research: Clinical Obstetrics and Gynaecology, v. 18, n. 6, p. 827-842, 2004. 
FUJII, R.A.X.; CORAZZA, M.J.; GALUCH, M.T.B. O que conhecem os estudantes do ensino superior sobre células-tronco. In: VII ENPEC (Encontro Nacional de Pesquisa em Educação em Ciência), 2009, Florianópolis/ sc. Atas do VII ENPEC Encontro Nacional de Pesquisa em Ensino de Ciências e E I CIEC Congreso Iberoamericano de Investigación em Enseñanza de Las Ciéncias, 2009.

LEMES, E.R.; FERREIRA, F.U.Y.; LEAL, B.E.S.; DIAS, J. ANTIQUEIRA, M.O.R. Percepções dos alunos do ensino fundamental sobre o uso de células tronco--embrionárias. Revista Espacios. v. 38 n. 5, p.19-25, 2017.

OLIVEIRA, R.R.; SIQUEIRA, J.E.; MATSUO, T. Avaliação do conhecimento sobre células-tronco observado em estudantes de graduação dos cursos da área da saúde da Universidade Estadual de Londrina: o que os alunos sabem e como se posicionam sobre o tema. O Mundo da Saúde, v. 32, n. 1, p. 39-46, 2008.

POURQUIÉ, O. Human embryonic stem cells get organized. Nature, v. 558, n. 7708, p. 35-36, 2018. Disponível em: <http://www.nature.com/articles/d41586-018-05115-y>.

SIVARAMAN, M.A.F. Ethical Guiding Principles of "Do No Harm" and the "Intention to Save Lives" in relation to Human Embryonic Stem Cell Research: Finding Common Ground between Religious Views and Principles of Medical Ethics. Asian Bioethics Review, [s. l.], v. 11, n. 4, p. 409-435, 2019. Disponível em: https://doi. org/10.1007/s41649-019-00103-4. Acesso em: 23 out. 2020.

SLACK, J.M.W. What is a stem cell? Wiley Interdisciplinary Reviews: Developmental Biology, v. 7, n. 5, p. e323, 1 set. 2018. Disponível em: <http://doi.wiley.com/10.1002/wdev.323>. Acesso em: 17 fev. 2019. 